\title{
The evolution of cephalometric diagnosis in Orthodontics
}

Maurício Barbosa Guerra da Silva1 ${ }^{1}$ Eduardo Franzotti Sant'Anna²

Introduction: Although the development of CT have represented a landmark in diagnostic imaging, its use in Dentistry turned out very discretely over the years. With the appearance of programs for analysis of three-dimensional images, specific for Orthodontics and Orthognathic surgery, a new reality is being built.

Objective: The authors of this study aim to inform the orthodontic society of fundamentals about digital cephalometric radiographic image and computed tomography, discussing about: Field of view (FOV), radiation doses, demands for the use in Orthodontics and radiographic simulations.

Keywords: Cone-Beam Computed Tomography. Digital dental radiography. Computer-assisted diagnosis.

Introdução: apesar do desenvolvimento da tomografia computadorizada ter representado um marco na área do diagnóstico por imagem, sua utilização em Odontologia deu-se de forma muito discreta ao longo dos anos. Com o surgimento de programas para análises de imagens tridimensionais, específicos para Ortodontia e Cirurgia Ortognática, uma nova realidade está sendo construída.

Objetivo: os autores do presente artigo têm o objetivo de informar à sociedade ortodôntica fundamentos sobre imagem radiográfica cefalométrica digital e tomografia computadorizada, discutindo sobre o campo de visão (FOV), doses de radiação, exigências para o uso em Ortodontia e simulações radiográficas.

Palavras-chave: Tomografia computadorizada de feixe cônico. Radiografia dentária digital. Diagnóstico por computador.

${ }^{1}$ Student of post-graduate education in Orthodontics at UFRJ.

${ }^{2}$ Assistant professor of Orthodontics at UFRJ.

» The patient displayed in this article previously approved the use of her facial and intraoral photographs.
How to cite this article: Silva MBG, Sant'Anna EF. The evolution of cephalometric diagnosis in Orthodontics. Dental Press J Orthod. 2013 May-June;18(3):63-71.

Submitted: September 15, 2009 - Revised and accepted: December 29, 2010

» The authors report no commercial, proprietary or financial interest in the products or companies described in this article.

Contact address: Eduardo Franzotti Sant'Anna

Av. Professor Rodolpho Paulo Rocco - Cidade Universitária - Ilha do Fundão CEP: 21.941-590 - Rio de Janeiro/RJ - Brazil

E-mail: eduardo.franzotti@gmail.com 


\section{INTRODUCTION}

In 1931, Orthodontics consecrated the era of cephalometry, from the historical works that presented to the orthodontic community, the cephalostat, device that allows the placement of the patient's head always on the same position., ${ }^{5,13}$ With this device, it was possible obtaining the serial radiographs that provided more accurate studies on the human facial growth. ${ }^{6}$ This year is considered a landmark for Orthodontics because of the evolution of the specialty as science.

In the late 60s, it began the era of computed cephalometric radiography. ${ }^{24}$ The technological evolution in data processing enabled the development of different programs that calculate distances and angles of the cephalometric tracing; reducing the manual work required on studies and consequently accelerating the researches where the cephalometric evaluation is necessary.

With computed tomography, using specific softwares, it began to be considered the possibility of simulating radiographs used in orthodontic diagnosis such as panoramic, lateral and frontal cephalometric; with the advantage of taking only one exam.

The role of extracting two-dimensional images from three-dimensional images becomes extremely important in this transition or change of paradigm from the $2 \mathrm{D}$ to the $3 \mathrm{D}$ diagnosis, so that the clinician can continue to use the same cephalometric analysis, until it is established consecrated three-dimensional analysis in orthodontic literature and become appealing to the day-by day practice. At first sight, it seems paradoxical the reconstruction of a 3D model and subsequent return to a $2 \mathrm{D}$ image, but this can make easier the progressive introduction of CBCT to the practice of the orthodontist ${ }^{21}$ and research.

Because of the progressive technological evolution for obtaining auxiliary images on the orthodontic diagnosis, the authors objective is to instruct the orthodontist about the use of the latest techniques for obtaining images.

\section{LITERATURE REVIEW}

\section{Digital cephalometric radiography}

The digital radiography is a versatile and reliable technology that increases the quality of diagnosis and the possibilities of image sharing in Dentistry.

Digital radiographic images can be produced by different means. Scanners with a transparency adapter, scanners of slides or any digital camera can be used to convert an existent analog radiograph to a digital image. This approach does not need high investment and allows bringing any radiograph to the digital system. The images produced by this technique usually are called indirect digital radiographs.

There are two systems, more advanced, for production of digital images, without a precursor radiograph: The direct and the semidirect. The direct digital images are obtained using a CCD sensor (charge-coupled device) and the semidirects using a system with a phosphor plate, as alternative to radiographic film. ${ }^{29}$

On the direct system, the images are obtained and automatically exported to a computer attached to the $\mathrm{X}$-ray device. On the semidirect, the capture source is a plate that contains crystals of phosphorus photo-stimulated by X-ray and that needs one more step to obtaining the images, which is the readout of the phosphor plate, performed by a scanner specific for this function, that sends the image to an attached computer.

It can be enumerated the advantages that the system of digital radiography offers over the conventional:

1) Allows visualization of the image while patient is still on the chair.

2) Reduces the risk of inappropriate association of the film to another patient's file.

3) Eliminates the possibility of printing mistakes.

4) Allows immediate correction of irregularities on brightness and contrast.

5) Promptly performs calibration of images.

6) Facilitates the overlap of the digital radiograph with the digital image. ${ }^{8,25,30}$

7) Provides images with quality superior than the conventional. $^{23}$

\section{Computed tomography}

The computed tomography is a method of diagnostic imaging that uses $\mathrm{x}$-radiation and allows obtaining the reproduction of a section of the human body in any of the three planes of space. It allows the visualization of the structures in slices, especially mineralized tissues, with good definition, allowing the diagnosis of possible alterations, in three dimensions. ${ }^{9,12}$

The traditional computed tomograph (CT) presents three main components: 1) the gantry, which has in its interior an X-ray tube and a ring of radiation detectors, consisted of scintillation crystals; 2) the table, which accommodates the patient lying and that, 
during examination, moves towards inside the gantry and 3) the computer, which reconstructs the tomographic image from the information obtained on the gantry (Fig 1). The CT technician or operator follows the examination through the computer, usually located outside the room that accommodates the gantry and the table, separated by a lead glass wall.

During exam, inside the gantry, the X-rays tube spin inside the stationary ring of receptors (Fig 2). The signals received by the detectors depend on the absorption of the tissues crossed by the radiographic beam and are recorded and processed, mathematically, on the computer. ${ }^{9}$

On the first generation of medical tomographs, the system captured only one slice at each spin of the set inside the gantry. The latest tomographs can obtain up to 64 slices simultaneously, reducing substantially the scanning time, besides improving the quality of

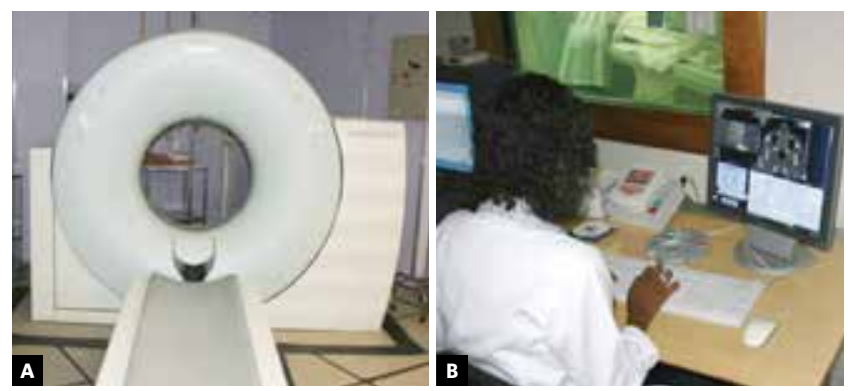

Figure 1 - Traditional computed tomograph: A) gantry and table; B) tomograph operator and computer.

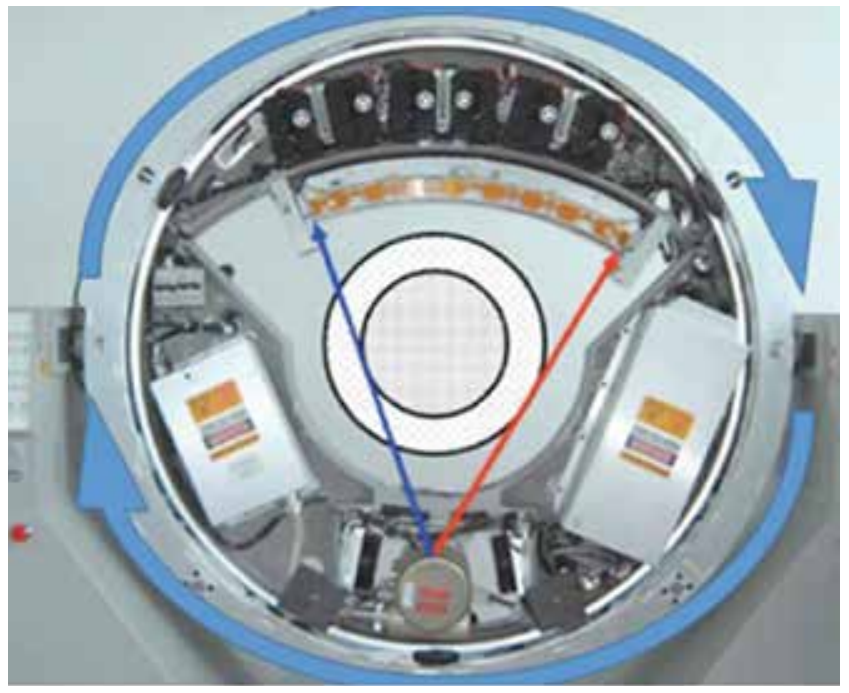

Figure 2 - Inner part of the gantry showing the source of X-rays, the receptor and the direction of spin of the components. (Source: Buzug 33, 2008). the image and reducing substantially the doses of radiation, when compared to their predecessors. ${ }^{15,26}$

When the patient has metallic restorations or uses metallic orthodontic appliance during examination, certain amount of artefacts affects the quality of the obtained image (Fig 3) and that was a remarkable disadvantage for that the fan-beam tomograph was not diffused in the dental area. ${ }^{14,28}$

Aiming to solve the limitations of conventional computed tomography, the department of radiology of the school of Odontology from the University of Nihon (Japan) developed, in 1997, a tomograph specific for Dentistry, using new technology, known as Cone-Beam Computed Tomography. ${ }^{2}$

Contrary to traditional tomographs, which are big and present high cost of acquisition and maintenance, the Cone-Beam tomograph has reduced size and can be installed in small physical spaces besides scanning only the patient's head, meeting the Dentistry needs. This technology allows the reproduction of threedimensional images of mineralized tissues with minimum distortion, lower cost and lower dose of radiation compared to traditional computed tomography. ${ }^{22,26}$

The conventional tomographs used a narrow source of beam, fan beam, that irradiated an arch-shaped receptor, obtaining one slice at a time. This required the reconstruction of the object slice by slice for obtaining its three-dimensional representation (Fig 4A). On the $\mathrm{CBCT}$, the rays are conically directed on a large flat sensor while both rotate around the patient's head, so that in a single rotation of the set (Fig 4B), which lasts between 20 and 40 seconds, nearly 360 2D slices are performed on the three planes of space. Then, a software reorganizes the slices in a 3D model including all irradiated structures, which can be digitally visualized in different ways. Compared to the conventional $\mathrm{CT}$, the CBCT uses significantly lower radiation, for it performs a single spin around the patient.

The representation of a two-dimensional image is composed of pixels, the short for "picture element". It's the smallest part of a digital image and each one of these parts contains information that determines its characteristics. The pixel is used as unit of measurement to describe the geometric dimension of an image and the larger the amount of pixels per inch, better the quality or resolution of the image. Each pixel brings the information about the level of gray or color that it represents. ${ }^{20}$ 

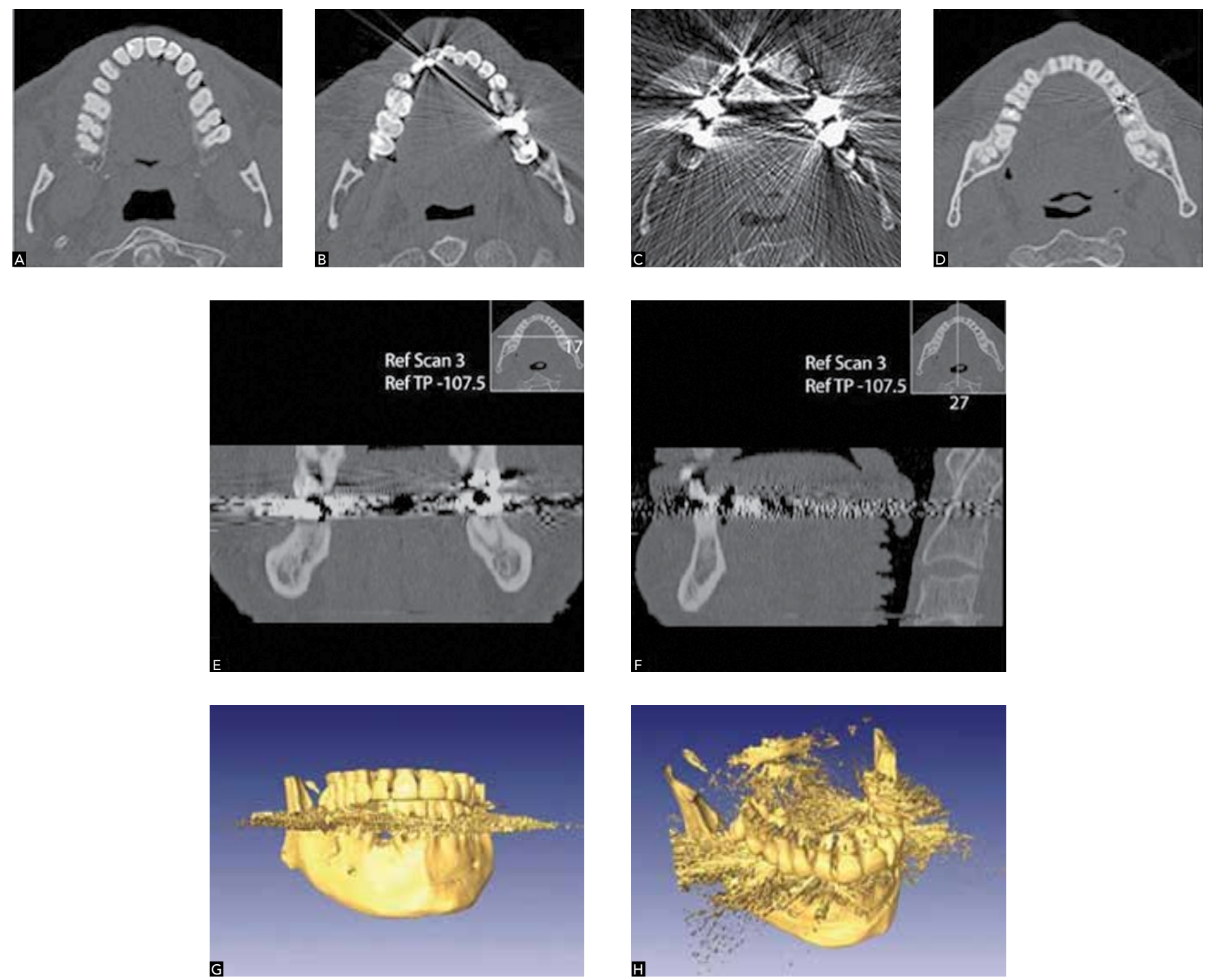

Figure $\mathbf{3}$ - Artefacts caused by metallic restorations on the images. On image A, axial incision without artefact, from $\mathbf{B}$ to $\mathbf{D}$, different levels of artefacts are found depending on the amount of metal present on the section; $\mathbf{E}$ and $\mathbf{F}$ show reconstructions of coronal and sagittal slices respectively; figures $\mathbf{G}$ and $\mathbf{H}$ show the 3D visualization emphasizing the axial slices that contained metals. Source: Buzug, ${ }^{33} 2008$

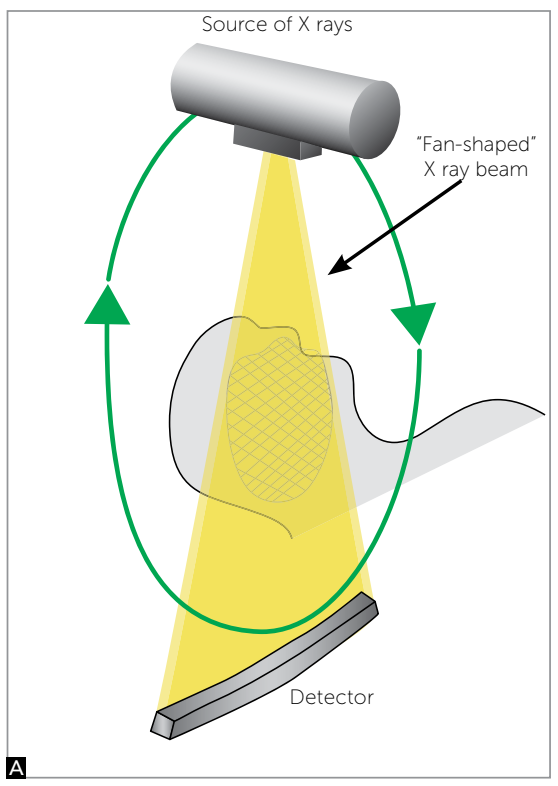

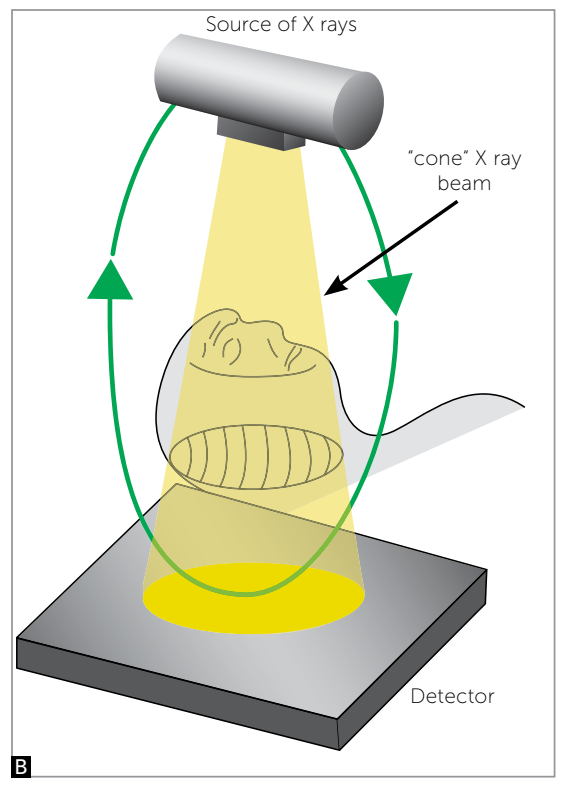

Figure 4 - Draft of projection of X-rays showing the differences on the obtention of image between a simple detector (A) and the cone beam (B). Source: Sukovic 272003 
The volumetric data are formed by voxels, which are the smallest structures makers of the 3D image. It would be a pixel with one more dimension, the depth. Its size determines the resolution of the three-dimensional image (Fig 5). On the CT, the voxels are anisotropic, rectangular cubes where the largest dimension is on the axial plan. Its depth is determined by the thickness of the tomographic section. Contrary to CTs, all CBCT devices generate images with isotropic voxels, i.e., similar in all three dimensions. ${ }^{3,26}$ On Figure 6 it can be visualized a plan emphasizing the difference between pixels and voxels.
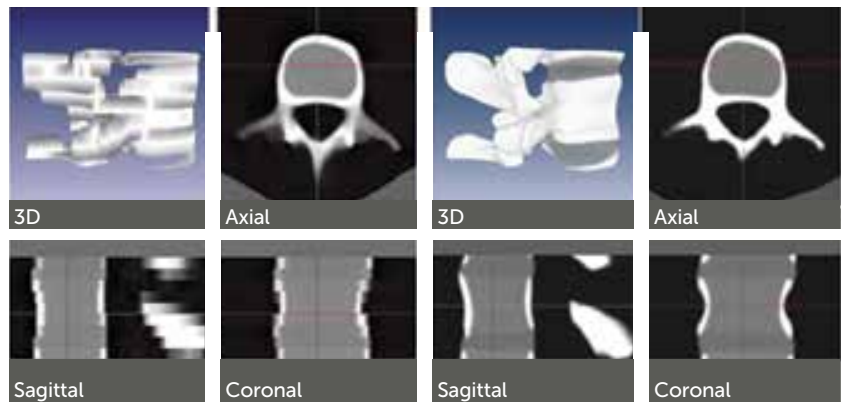

Figure 5 - Images of the same region (vertebra) with different configuration of CT. Images on the left were performed with slices thickness of $6 \mathrm{~mm}$, while on the right with $0,5 \mathrm{~mm}$. Source: Buzug, ${ }^{33} 2008$

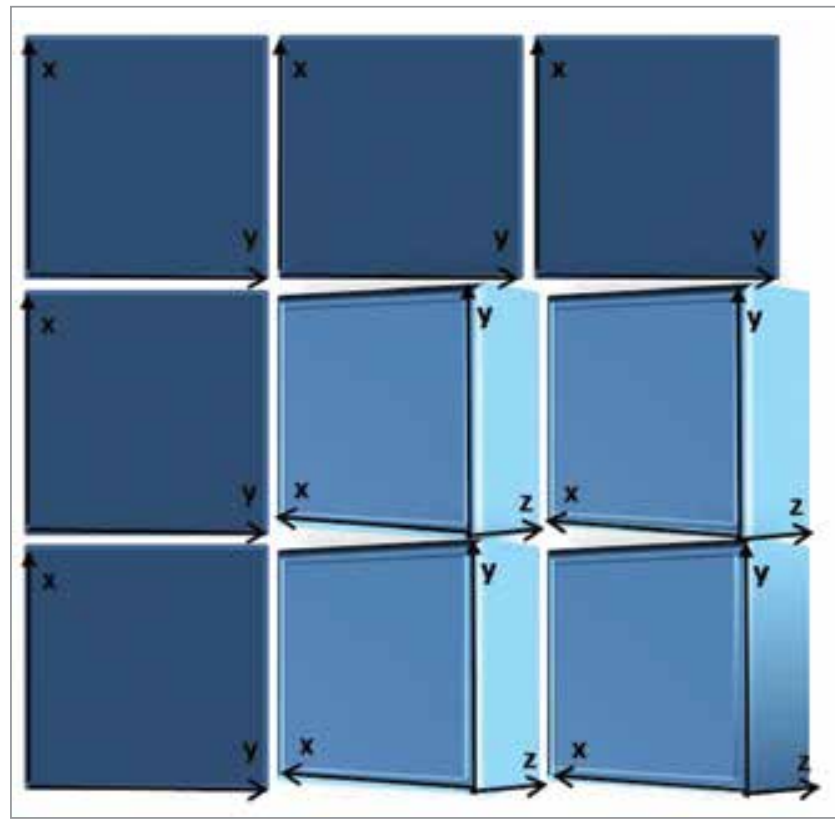

Figure 6 - Scheme showing the pixels in two dimensions $(x, y)$ and the voxels in three dimensions $(x, y, z)$.

\section{Field of view}

The field of view or FOV of the cone beam devices, normally work with windows between 6 -in and 12-in. The FOV of 6-in is used when you want images restrict to only one of the jaws. On the FOV of 9-in it is possible to visualize both jaws, and depending on the size of the patient, all the craniofacial complex. However, when you want all the craniofacial region inserted in the study, as in cases where you want to cephalometrically analyze the patient, you must select the FOV of 12-in (Fig 7). . $^{3,716,18}$

The structures and reference points used on the orthodontic analysis comprise the skull base, the facial bones and the dentition, which requires a field of view larger than the used on the analysis for implants. In general, the orthodontist needs to visualize the nasion, on the anterior-superior border of the image, and the mandibular points pogonion, gnathion and mentum on the anterior-inferior border. The posterior field of view must include the sella turcica, the TMJs (condyle point), skull base (basion), and the posterior contour of the mandible (gonion). Besides, the vertebrae until C4, should be visible on the tomography, allowing analysis of the skeletal maturation. ${ }^{21}$

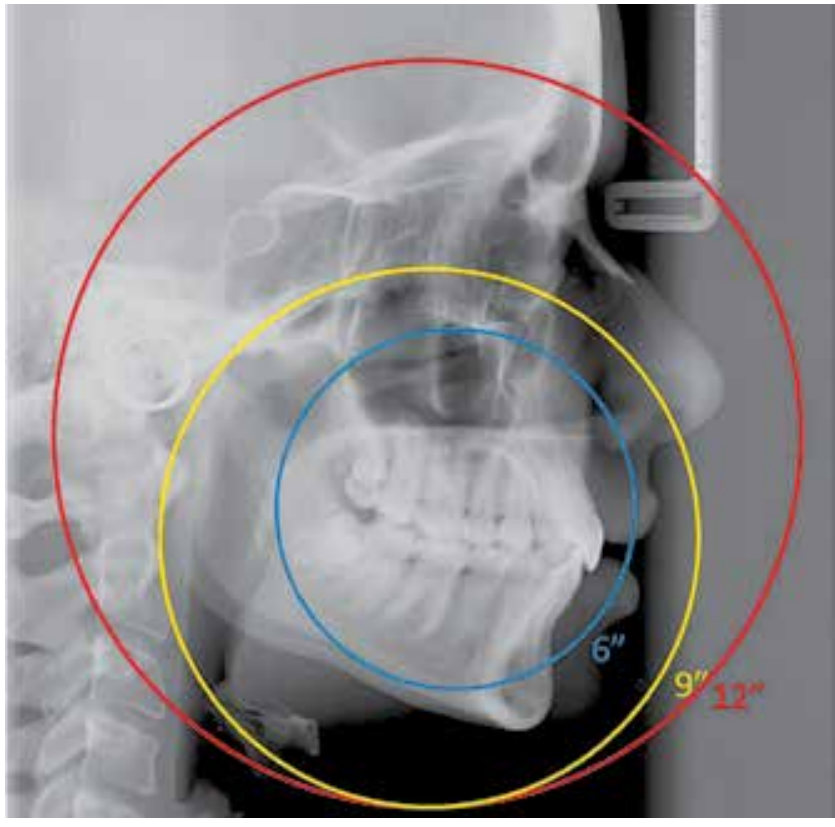

Figure 7 - Image showing the different sizes of FOV (6, 9 and 12 inches). 


\section{Radiation doses}

One of the main disadvantages of $\mathrm{CT}$ is the fact that it uses x-radiation, which has negative effect on the human body, especially for the capacity to cause mutation, detectable in cells that multiply quickly, as in the case of cells from the buccal mucosa. Although the risk of developing anomalies is low, it is not recommended the performance of CTs on pregnant women, considering very carefully the risks and benefits. ${ }^{1,17,19}$

It is known in radiological literature that a full periapical exam may vary from 33 to 150 microsieverts $(\mu \mathrm{Sv})$, depending on the film and type of collimation used. ${ }^{4,32}$ A panoramic review varies from 2,5 to $6,2 \mu \mathrm{Sv}$ (digital) and from 3 to $10 \mu \mathrm{Sv}$ (film), depending on the equipment and the quality of the required image. ${ }^{10}$ Effective doses for digital cephalometric radiographs vary from 1,1 to $3,4 \mu \mathrm{Sv}$, depending on the type of system, ${ }^{11}$ while the reported dosage with the use of film is of $2,3 \mu \mathrm{Sv} .{ }^{31}$ As parameter, it is known that the mean environmental radiation (cosmic radiation, radiation from the ground, UV rays) is of $3000 \mu \mathrm{Sv} /$ year (around $8 \mu \mathrm{Sv} /$ day), which means that the dosage of a cephalometric and panoramic radiograph is equivalent to half of a day and to one day of environmental radiation, respectively (Table 1$).{ }^{21}$

A research compared the dosimetry of three tomographs, all using the field of view of 12-in, exactly the one of orthodontic interest. ${ }^{18}$ Various doses were found, measurements in $\mu \mathrm{Sv}$ according to norms by the International Committee of Radiologic Protection (ICRP) of 1990 and 2005, so that the i-CAT presented dosage from 135 to $193 \mu \mathrm{Sv}$, higher than the NewTom (45 to $59 \mu \mathrm{Sv}$ ), while the CB MercuRay showed a dosage significantly higher, from 477 to $558 \mu \mathrm{Sv}$. That is, the i-CAT and the MercuRay presented doses 3 to 3,3 times and 9,5 to 10,7 times higher than the NewTom, respectively. Besides, the CBCT equipments presented doses from 4 to 42 times higher than a panoramic radiograph $(6,3-13,3 \mu \mathrm{Sv})$.
The authors concluded that the dosage ranged substantially depending on the equipment, on the FOV and on specific technical factors $(\mathrm{mA}$ and $\mathrm{kV})$. On the i-CAT, the variation of FOV from 12-in to 9-in reduced the dosage from $135-193 \mu \mathrm{Sv}$ to $69-105 \mu \mathrm{Sv}$. The CB MercuRay, for example, tested on FOV of 12-in with $10 \mathrm{~mA} / 100 \mathrm{kV}$ and $15 \mathrm{~mA} / 120 \mathrm{kV}$, showed values of 477-558 $\mu \mathrm{Sv}$ and $847-1025 \mu \mathrm{Sv}$, respectively.

\section{Orthodontic demands}

Some basic requirements must be considered so that a CBCT equipment is appropriated for orthodontic diagnosis, such as: Have a field of view including all structures of orthodontic interest and allow visibility of soft and hard tissues, with good resolution. It is known that this method is ideal to irradiate teeth and bones, while other methods, as magnetic resonance, would be more recommended for better resolution of soft tissues.

The advantage of relative short period of examination, when compared to fan beam tomograph, may affect the quality of the final image, because it reduces the possibility of artefacts by movimentation of the head. Some equipments bring a head positioner, with support for the mentum and splint for the forehead, but its use must be avoided believing that it may cause distortion on the soft tissues, besides affecting the mandibular positioning. ${ }^{21}$

The cone beam computed tomographs most known on the international market with adequate characteristics for orthodontic use are the NewTom 3G (AFP Imaging, Elmsford, New York, USA), i-CAT (Imaging Sciences International, Hatfield, Pennsylvania, USA) and CB MercuRay (Hitachi Medical Corporation, Tokyo, Japan) (Table 2).

Besides the equipments available today, the trend is that manufacturers develop new systems presenting better x-ray sensors and programs of reconstruction and visualization of the images improved and of easy handling.

Table 1 - Comparison between the dose of radiation of different radiographic and tomographic devices. Source: Motta, ${ }^{21} 2007$

\begin{tabular}{cccc}
\hline Reference & Environmental radiation & Cephalometric & Panoramic \\
Radiation $(\mu \mathrm{Sv})$ & $8 /$ day $(3000 /$ ano $)$ & $1,1-3,4$ & $2,5-10$ \\
Equipment & NewTom 3G & i-CAT & CB MercuRay \\
Radiation $(\mu S v)$ & $45-59$ & $135-193$ & $477-558$ \\
\hline
\end{tabular}


Radiographic simulation

Through CBCT technology, all the radiographs possible on the dentomaxillofacial region are obtained in a single exposition, for the technique enables the capture of all the object's volume, in a period inferior to 1 minute. Through this, the orthodontist has diagnostic quality on periapical, panoramic, cephalometric, occlusal, spatial view of temporomandibular

Table 2 - Comparison between characteristics of a medical tomograph and a cone beam one. Source: Adapted from Danforth ${ }^{7} 2003$.

\begin{tabular}{|c|c|c|c|c|}
\hline Parameters & NewTom 3G (Aperio) & i-CAT (Imaging Sciences) & CB MercuRay (Hitachi) & Medical tomograph \\
\hline Irradiated area & Head & Head & Head & Full body \\
\hline X-ray beam & Conical & Conical & Conical & Fan \\
\hline Patient's position & Lying & Sitting & Sitting & Lying \\
\hline Exam (time) & $36 s$ & $20-40 s$ & $11 \mathrm{~s}$ & Depend on the exam ( $\pm 10 \mathrm{~min}$.) \\
\hline Exposition period & $5.4 \mathrm{~s}$ & $3.3 \mathrm{~s}$ & $9.6 \mathrm{~s}$ & Depend on the exam (> 2 min.) \\
\hline \multirow{2}{*}{ Detection sensor } & Area & Area & Area & Linear \\
\hline & CCD images intensifier & Amorphous silicon flat panel & CCD images intensifier & Gas or solid state \\
\hline Voxel $\left(\mathrm{mm}^{3}\right)$ & $0,07-0,20$ & $0,2-0,4$ & $0,1-0,4$ & 0,317 \\
\hline \multirow{2}{*}{ Obtention } & Panoramic & Panoramic & Panoramic & Axial sections \\
\hline & Single rotation $360^{\circ}$ & Single rotation $360^{\circ}$ & Single rotation $360^{\circ}$ & Multiple rotations $360^{\circ}$ \\
\hline
\end{tabular}

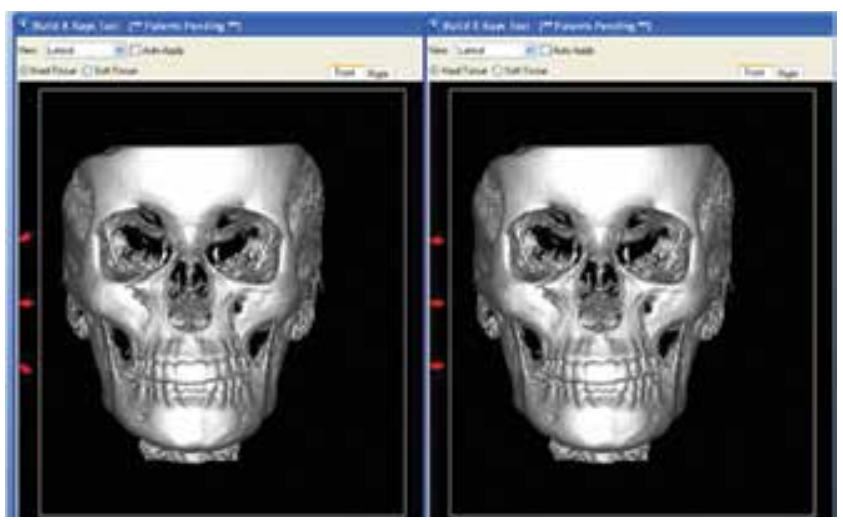

Figure 8 - Illustration of the configuration with divergence or parallelism of $X$-rays. Note the detail on the left.

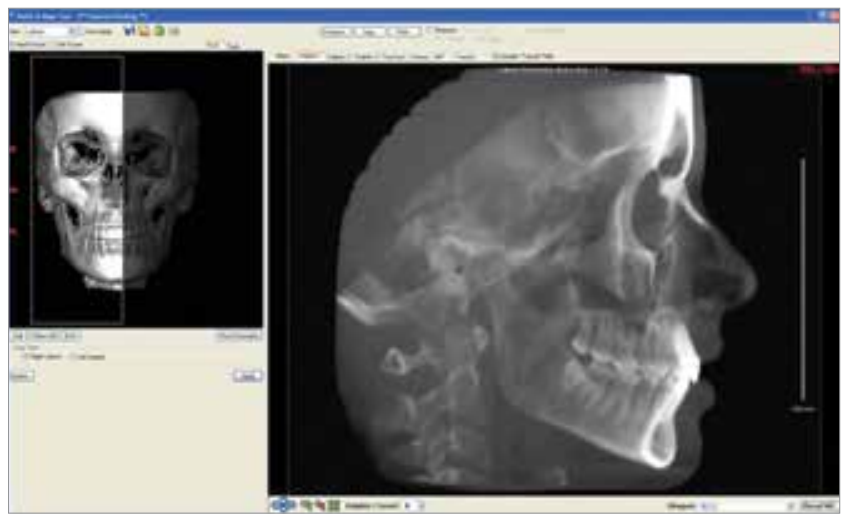

Figure 10 - Prospective cephalometric radiograph including only the right side of the image.

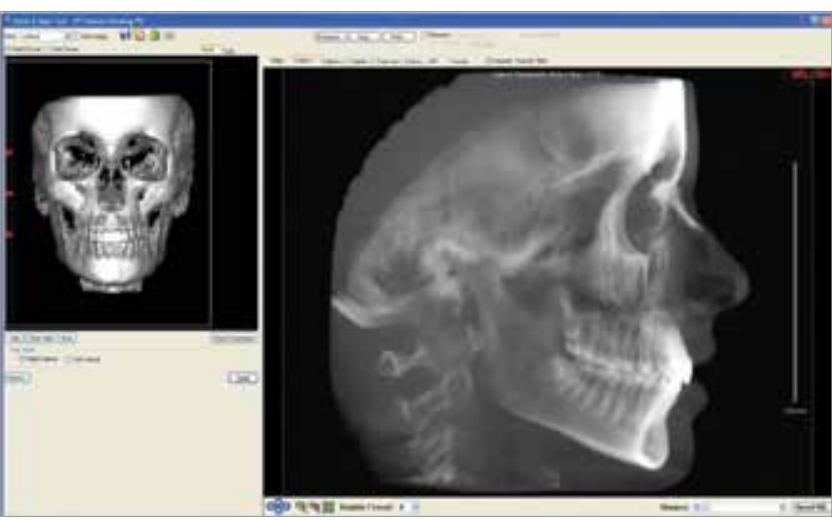

Figure 9 - Prospective cephalometric radiograph including the two sides of the image.

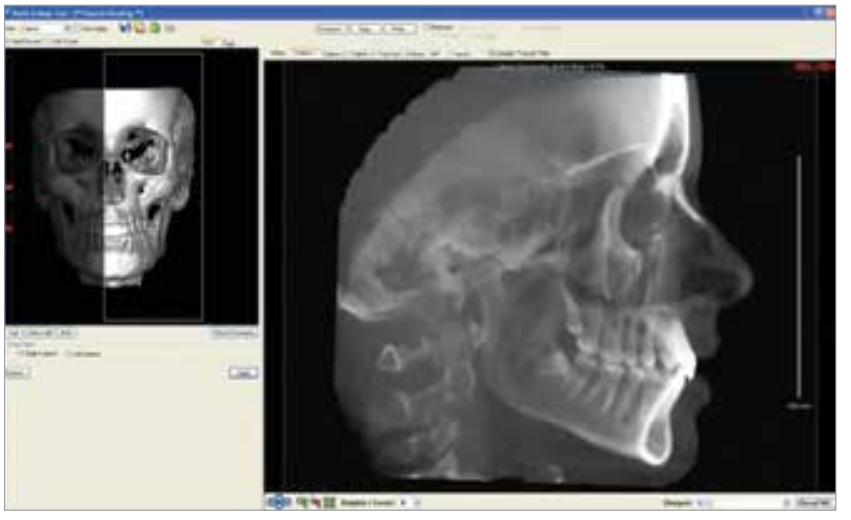

Figure 11 - Prospective cephalometric radiograph including only the left side of the image. 
joint (TMJ), as well as has the possibility to separate the right and left side of the face, on cephalometric analysis, reducing the overlap of bone structures. ${ }^{27}$

The cephalometric radiograph can be simulated from a tomograph with different characteristics, presenting advantageous possibilities. On the simulation of cephalometric radiograph, the volumetric model rebuilt from the tomographic sections is spatially oriented by the operator, as if positioned the patient's head on the cephalostat of conventional teleradiographic equipment, and then it is projected on a two-dimensional image (Fig 9). On the moment of the radiographic simulation, some software as the Dolphin Imaging 3D (Dolphin Imaging \& Management Solutions, Chatsworth, California), and the InVivo (Anatomage, San Jose, California, USA) allow adjustments related to divergence or parallelism of rays (Fig 8). It is possible to choose between two configurations: Prospects or Orthogonal. The prospective radiograph is the closest to conventional cephalometrics, for it is simulated with divergence of rays, resulting in a magnification of the image inherent to the technique, causing different extensions between the structures on the left and right side of the face, especially on the lower borders of the mandible. On the orthogonal radiograph, when the projection of rays is parallel, there is a maintenance on the size relation 1:1 for both sides of the face, characteristic of the tomographic take.

When generating the cephalometric, there is the frontal view of the three-dimensional volume and reference lines are provided for a correct positioning of the three-dimensional volume. A window is provided, which works to determine how much of the image must constitute the simulated radiograph. Interesting possibility is the generation of a radiograph for each half of the head, removing the superposition of bilateral structures of the face. It can be simulated at least 3 different images for each configuration (orthogonal or prospects). On Figure 9 there is an image with superpositions, where all the volume was selected; on Figure 10, there is a simulation that includes only the right side of the image, and on Figure 11, there is only the left side structures composing the simulated radiograph.

\section{CONCLUSION}

It is extremely important that the orthodontist is always informed about the evolution on techniques of obtaining images, fundamental for diagnosis, so that technology is a strong ally for the success of orthodontic treatments of his patients. 


\section{REFERENCES}

1. Angelieri F, Oliveira GR, Sannomiya EK, Ribeiro DA. DNA damage and cellular death in oral mucosa cells of children who have undergone panoramic dental radiography. Pediatr Radiol. 2007:37(6):561-5. Epub 2007 Apr 24

2. Arai Y, Tammisalo E, Iwai K, Hashimoto K, Shinoda K. Development of a compact computed tomographic apparatus for dental use. Dentomaxillofac Radiol. 1999;28(4):245-8.

3. Araki K, Maki K, Seki K, Sakamaki K, Harata Y, Sakaino R, et al. Characteristics of a newly developed dentomaxillofacial X-ray cone beam CT scanner (CB MercuRay): system configuration and physical properties. Dentomaxillofac Radiol. 2004;33(1):51-9.

4. Avendanio B, Frederiksen NL, Benson BW, Sokolowski TW. Effective dose and risk assessment from detailed narrow beam radiography. Oral Surg Oral Med Oral Pathol Oral Radiol Endod. 1996:82(6):713-9.

5. Broadbent HB. A new X-ray technique and its application to orthodontia. Angle Orthod. 1931;1(2):45-66

6. Broadbent HB. The face of normal child. Angle Orthod. 1937;7(4):183-208

7. Danforth RA, Dus I, Mah J. 3-D volume imaging for dentistry: a new dimension. J Calif Dent Assoc. 2003:31(11):817-23.

8. Farman AG, Levato CM, Gane D, Scarfe WC. In practice: how going digital will affect the dental office. J Am Dent Assoc. 2008;139 Suppl:14S-19S

9. Garib DG, Raymundo Jr. R, Raymundo MV, Raymundo DV, Ferreira SN. Tomografia computadorizada de feixe cônico (Cone beam): entendendo este novo método de diagnóstico por imagem com promissora aplicabilidade na Ortodontia. Rev Dental Press Ortod Ortop Facial. 2007:12(2):139-56

10. Gijbels F, Jacobs R, Bogaerts R, Debaveye D, Verlinden S, Sanderink G. Dosimetry of digital panoramic imaging. Part I: Patient exposure. Dentomaxillofac Radiol. 2005;34(3):145-9.

11. Gijbels F, Sanderink G, Wyatt J, Van Dam J, Nowak B, Jacobs R. Radiation doses of indirect and direct digital cephalometric radiography. $\mathrm{Br}$ Dent J. 2004;197(3):149-52; discussion 140

12. Hajeer MY, Millett DT, Ayoub AF, Siebert JP. Applications of 3D imaging in orthodontics: part I. J Orthod. 2004:31(1):62-70

13. Hofrath $\mathrm{H}$. Die Bedeutung der Röntgenfern- und Abstandsaufnahme für die Diagnostik der Kieferanomalien. Fortschritte Orthod. 1931;1:232-58.

14. Holberg C, Steinhäuser S, Geis P, Rudzki-Janson I. Cone-beam computed tomography in orthodontics: benefits and limitations. J Orofac Orthop. 2005:66(6):434-44

15. $\mathrm{Hu} \mathrm{H}, \mathrm{He} \mathrm{HD}$, Foley WD, Fox SH. Four multidetector-row helical CT: image quality and volume coverage speed. Radiology. 2000;215(1):55-62.

16. Kau CH, Richmond S, Palomo JM, Hans MG. Three-dimensional cone beam computerized tomography in orthodontics. J Orthod. 2005;32(4):282-93.
17. Koturbash I, Rugo RE, Hendricks CA, Loree J, Thibault B, Kutanzi K, et al. Irradiation induces DNA damage and modulates epigenetic effectors in distant bystander tissue in vivo. Oncogene. 2006;25(31):4267-75. Epub 2006 Mar 13.

18. Ludlow JB, Davies-Ludlow LE, Brooks SL, Howerton WB. Dosimetry of 3 CBCT devices for oral and maxillofacial radiology: CB Mercuray, NewTom 3G and i-CAT. Dentomaxillofac Radiol. 2006:35(4):219-26.

19. Maillie HD, Gilda JE. Radiation-induced cancer risk in radiographic cephalometry. Oral Surg Oral Med Oral Pathol. 1993;75(5):631-7.

20. Mohan A, Tumblin J, Choudhury P. Editing soft shadows in a digital photograph. IEEE Comput Graph Appl. 2007;27(2):23-31.

21. Motta AT. Avaliação da cirurgia de avanço mandibular por meio da superposição de modelos tridimensionais [tese]. Rio de Janeiro (RJ): Universidade Estadual do Rio de Janeiro; 2007.

22. Nakajima A, Sameshima GT, Arai Y, Homme Y, Shimizu N, Dougherty H Sr. Two- and three-dimensional orthodontic imaging using limited cone beam-computed tomography. Angle Orthod. 2005:75(6):895-903.

23. Näslund EB, Kruger M, Petersson A, Hansen K. Analysis of low-dose digital lateral cephalometric radiographs. Dentomaxillofac Radiol. 1998:27(3):136-9.

24. Ricketts RM. The evolution of diagnosis to computerized cephalometrics. Am J Orthod Dentofacial Orthop. 1969:55(6):795-803.

25. Sarver DM, Johnston MW. Digital imaging in orthodontics. In: Jacobson A, editor. Radiographic cephalometry: from basics to 3-D imaging. Chicago: Quintessence; 2006. p. 219-31.

26. Scarfe WC, Farman AG, Sukovic P. Clinical applications of conebeam computed tomography in dental practice. J Can Dent Assoc. 2006;72(1):75-80

27. Sukovic P. Cone beam computed tomography in craniofacial imaging Orthod Craniofac Res. 2003;6 Suppl 1:31-6; discussion 179-82.

28. Swennen GR, Schutyser F. Three-dimensional cephalometry: spiral multislice vs cone-beam computed tomography. Am J Orthod Dentofacial Orthop. 2006:130(3):410-6.

29. Van der Stelt PF. Filmless imaging: the uses of digital radiography in dental practice. J Am Dent Assoc. 2005:136(10):1379-87.

30. Van der Stelt PF. Better imaging: the advantages of digital radiography J Am Dent Assoc. 2008:139 Suppl:7s-13s.

31. Visser H, Rodig T, Hermann KP. Dose reduction by direct-digital cephalometric radiography. Angle Orthod. 2001;71(3):159-63.

32. White SC. 1992 assessment of radiation risk from dental radiography Dentomaxillofac Radiol. 1992;21(3):118-26

33. Buzug TM. Computed tomography: from photon statistics to modern Cone-beam CT. Lübeck: Springer, 2008. 